\title{
Communication
}

\section{Isolation of Fungal Pathogens of Stored Maize, Zea mays L., in Seka Chokersa District of Jimma Zone, Ethiopia}

\author{
Garuma Nemera Roge \\ Holetta Agricultural Research Center, Holetta, Ethiopia \\ Email address: \\ grmn2007@gmail.com
}

\section{To cite this article:}

Garuma Nemera Roge. Isolation of Fungal Pathogens of Stored Maize, Zea mays L., in Seka Chokersa District of Jimma Zone, Ethiopia. American Journal of Life Sciences. Vol. 9, No. 3, 2021, pp. 42-44. doi: 10.11648/j.ajls.20210903.11

Received: April 1, 2021; Accepted: May 19, 2021; Published: May 27, 2021

\begin{abstract}
Maize, the most common stable food in Africa, is attacked by different pests during its production and post-harvest. Fungi are usually responsible for the deterioration of maize seedlings and grains right in the field or in storage. Storage fungi usually invade grain or seed during storage and are generally not present in large quantities before harvest in the field. They cause quality loss through their production of toxic byproducts which has high risk for human and animal health. The most common storage fungi are species of Aspergillus and Penicillium. This short study was conducted with an objective of isolating and identifying the major fungi genera associated with stored maize grain in Seka Chokersa district of Jimma Zone in 2017. Samples were taken from farmers traditional storage containers. For isolation, the fungi were grown on PDA medium and identified morphologically using a dissecting microscope. Accordingly, common stored cereal grain fungi genera Aspergillus, Fusarium and Penicillium were morphologically identified off the samples collected to their genus level. Among these fungi, Aspergillus spp. was identified with high frequency (86.6\%) followed by Fusarium spp. (53.3\%) and Penicillium spp. (40\%). Aspergillus, Fusarium and Penicillium are among the top fungi genera deteriorating stored cereal grain which have high health risk for both human and animal.
\end{abstract}

Keywords: Stored Cereal Grain, Fungal Pathogen, Fungi Genera, Aflatoxin

\section{Introduction}

Maize (Zea mays L.) is among the top cereal crop which has food and feed importance, raw materials for industrial processing [1]. It is one of the stable food crops largely produced in Ethiopia [2]. Losses up to $50-80 \%$ can be occurred in stored maize due to storage fungi provided favorable conditions existed for fungi development during the storage period [3].

In Ethiopia, maize grain storage structures are usually open-air storage structures which expose to moisture and related pest activities resulting in damage to stored grain. According to Demissie et al. [4], 100\% loss of stored maize can occur due to maize weevils' damage and subsequent mold development at storage level. Fungi are important postharvest pests causing deterioration and loss of stored maize grain next to insects [5]. They are among the principal causes of deterioration and yield loss on farmers' maize during the storage period. Several fungi species are attributed to maize seeds causing deterioration during storage period. The conditions at which the maize grains arrive at the store determine the fungi that predominate and the subsequent infection by the storage fungi. Fungi such as rhizopus, mucor, rhizoctonia, cladosporium, trichothecium, fusarium and altenaria are common on grains harvested immaturely. Fungi that develop on grains during storage usually survive at low moisture contents, the typical examples are Aspergillus, Penicillium and Fusarium are the major fungi genera typically found in stored grains, several of which are capable of producing toxins [6, 7]. Aspergillus flavus systematically produces Aflatoxin in seedling of maize and damage stored maize which has high risk to human health. Fusarium principally invades more than $50 \%$ pre-harvest maize grain and produces mycotoxin $[5,8]$. Several internal and external factors can affect the development of these fungi, some of which are the moisture content of the product, temperature, storage time, and degree of fungal contamination prior to storage, insects and mite activity that facilitates fungi dissemination [9].

Sode et al. [10] reported that poor post-harvest practices 
aggravate post-harvest pests' development which in some cases results in losses exceeding $50 \%$ of stored product. And, the greatest yield loss is from mould developed on poorly handled stored products [11]. Yield losses due to physical and mechanical damage during harvesting are considerable on which pests such as insects and rodents are common [12].

Human and animal health, and seed quality reduction in storage are concerned because of the seriousness of mycotoxins in grains and other staple foods and feed stuffs. In spite of the importance of these postharvest pathogens, there is a limited information on the occurrence and prevalence of these fungi among many farmers in Ethiopia particularly in Jimma zone where maize is the top stable food. This mini study was conducted with the objective of identifying fungi pathogens of stored maize grain in Seka Chokersa district of Jimma Zone, Ethiopia.

\section{Materials and Methods}

\subsection{Study Area and Sample Collection}

The study was conducted in Seka Chokersa district of Jimma Zone, Ethiopia in 2017. The district is situated at $7^{\circ} 29^{\prime} 59.99^{\prime \prime} \mathrm{N}$ and $36^{\circ} 04^{\prime} 60.00^{\prime \prime} \mathrm{E}$ with an elevation range of 1580 to 2560 m.a.s.l. Samples were collected from stored maize grains; three months later to storage time with the expectation of high infestation level during this time. The study district was selected based on its maize production potential. Twenty farmer stores were sampled from the district at random. Samples were carefully diagnosed for the occurrence any genus of fungus.

\subsection{Laboratory Study}

The collected grains were surface disinfected with $\mathrm{NaOCl}$. Five seeds were plated on petri-dish of $9 \mathrm{~cm}$ diameter poured with PDA medium. The seeds were incubated for pathogens on the seeds to grow. Identification of each fungus was done to genus level based on its morphological characteristics (Figures 1 to 3). For each fungus genus identified, percent of isolation frequency (IF) was done using the formula used Marasas et al. [13].

$$
\text { IF }(\%)=\frac{\text { number of samples of occurrence of fungi species }}{\text { total number of samples }} * 100
$$

\section{Results and Discussion}

In this study, three most important stored grain fungi, Aspergillus, Fusarium and Penicillium were isolated, characterized and identified microscopically to their genus level (Figures 1 to 3). Of the fungi identified, Aspergillus spp. was the most frequently occurred $(86.6 \%)$ storage fungus followed by Fusariun spp. (53.3\%) and Penicillium spp. (40\%) (Table 1).

Table 1. Frequency of occurrence and percent isolation frequency of the fungal genera identified.

\begin{tabular}{llll}
\hline $\begin{array}{l}\text { Number of isolates } \\
\text { with fungus }\end{array}$ & Fungal genera identified & $\begin{array}{l}\text { Frequency of occurrence of each } \\
\text { fungus genus }\end{array}$ & Percent isolation Frequency, IF (\%) \\
\hline \multirow{3}{*}{15} & Aspergillus spp. & 13 & $86.6 \%$ \\
& Fusarium spp. & 8 & $53.3 \%$ \\
& Penicillium spp. & 6 & $40 \%$ \\
\hline
\end{tabular}

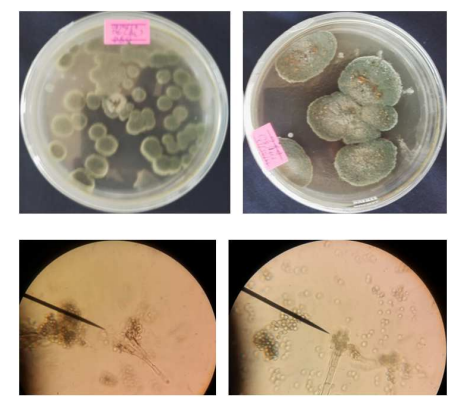

Figure 1. Penicillium spp.

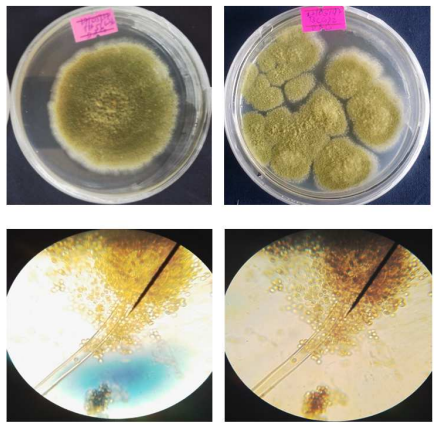

Figure 2. Aspergillus spp.

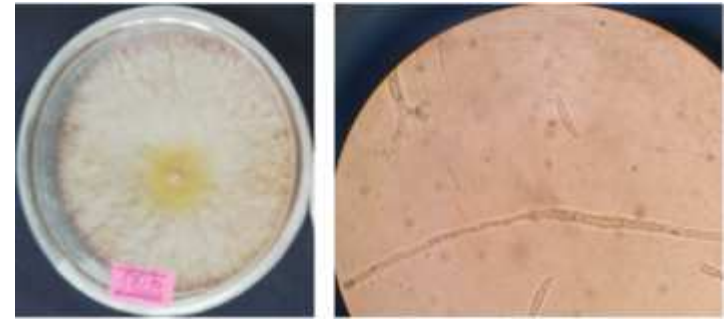

Figure 3. Fusarium spp.

The results agree with the findings of different researches on mycoflora of stored maize grain in which these storage fungi are common [14, 15]. Many studies report that Aspergillus spp. is the most important and frequently isolated storage fungus of the common stored grain fungi genera which this study also confirmed [1, 16, 17]. Some findings also report that the fungi genera identified in this study were common in traditional storage containers of the study area [16]. Similar findings in Adetunji et al. [18], Negasa et al. [19], Aminu and Keta [20] and Sharma and Sharma [21] also indicate that these fungi are common in traditional storage structures of farmers with their respective mycotoxins being a serious concern in all reports. 


\section{Conclusion}

Maize is affected by several fungi genera before harvest and during post-harvest. Contamination of seed and grain with fungal organisms may result in poor germination, seedling vigor or grain quality. Contamination occurs through small quantities of spores contaminating the grain as it is going into storage from the harvest, in handling and storage equipment or from spores already in the storage structures. Under high temperatures and moisture, this small amount of inoculum can increase rapidly. Fungi cause two distinct problems in storage grains: spoilage from fungal growth or molds and the production of poisonous mycotoxins. Mycotoxins are fungi byproducts, poisonous chemical compounds produced by certain fungal species that infect crops.

The current results revealed that during storage period, a series of storage fungi can be developed in stored maize among which potentially toxigenic species of fungi genera such as Aspergillus spp. are significant in traditional maize storage. The study also indicated that Aspergillus spp., Fusarium spp. and Penicillium spp. were the major stored maize fungi genera in the study area. These fungi genera produce byproducts which are risky to human and animal health.

\section{Conflict of Interest}

No conflict of interest is concerned on the manuscript.

\section{Acknowledgements}

I am grateful to staff of Plant Pathology of College of Agriculture and Veterinary Medicine (JUCAVM) of Jimma University.

\section{References}

[1] Krnjaja V, Stanković SZ, Petrović TS, Tomić Z, Mandic V and Bijelic Z (2013). Moulds and mycotoxins in stored maize grains. Biotechnology in Animal Husbandry, 29 (3), pp. 527-536.

[2] CSA (Central Statistical Agency) (2012). The Federal Democratic Republic of Ethiopia Agricultural Sample Survey 2011 / 2012. Volume I, Report on Area andF Production of Major Crops (Private Peasant Holdings, Meher Season).

[3] Tsedaley B and Adugna G (2016). Detection of fungi infecting maize (Zea mays L.) seeds in different storages around Jimma, South-Western Ethiopia. Journal of Plant Pathology \& Microbiology, 7 (3), p. 338.

[4] Demissie G, Teshome A, Abakemal D, Tadesse A (2008). Cooking oils and "Triplex" in the control of Sitophilus zeamais Motschulsky (Coleoptera: Curculionidae) in farm-sored maize. Journal of Sored Products Research, 44 (2), pp. 173-178.

[5] Uzma S and Shahida A (2007). The screening of seven medicinal plants for artificial activity against seed borne fungi of maize seeds. Pakistan Journal of Botany, 39 (1): 285-292.
[6] Castlellarie C, Marcos Valle F, Mutti J, Cardoso L and Bartosik $R$ (2010). Toxigenic fungi in corn (maize) stored in hermetic plastic bags. Julius-Kuhn-Archiv, (425), pp. 501-504.

[7] Richard JL (2007). Some major mycotoxins and their mycotoxicoses: An overview. Int J Food Microbial 119: 3-10.

[8] Charity A., Amienyo J and Dauda T (2010). Effect of relative humidity on spore determination and growth of Aspergillus flavus. Nigerian Journal of Botany, 23 (1): 1-6.

[9] Suleiman MN and Omafe OM (2013). Activity of three medicinal plants on fungi isolated from stored maize seeds (Zea mays L.). Global Journal of Medicinal Plant Research, 1 (1), pp. 77-81.

[10] Sode OJ, Mazoud F and Troude F (1995). Economics of grain storage. In: Jayas DS, White NDG, White WE. (eds.). Stored-grain Ecosystems. Marcel Dekker. pp. 101-122.

[11] Ominski KH, Marquardt RR, Sinha RN and Abramson D (1994). Ecological aspects of growth and mycotoxin production by storage fungi. Mycotoxins in grains. Compounds other than Aflatoxin. Eagen Press, USA. pp. 287-305.

[12] Udoh JM, Cardwell KF and IkotunT (2000). Storage structures and aflatoxin content of maize in five agro-ecological zones of Nigeria. Journal of Stored Products Research 36 (2), 187-201.

[13] Marasas W, Burgess LW, Anelich RY, Lamprecht SC van Schalkwyk DJ (1988). Survey of Fusarium species associated with plant debris in South African soils. South African Journal of Botany, 54 (1), pp. 63-71.

[14] Hassan FF, Al-Jibouri MH and Hashim AKJ (2014). Isolation and Identification of Fungal Propagation in Stored Maize and detection of aflatoxin B1 Using TLC and ELISA Technique. Iraqi Journal of Science, 55 (2B), pp. 634-642.

[15] Dudoiu R, Cristea S, Lupo C, Popa D and Opera M (2016). Micoflora associated with Maize grains during storage period. AgroLife Scientific Journal, 5 (1), pp. 63-68.

[16] Dubale B, Solomon A, Geremew B, Sethumadhava RG and Waktole S (2014). Mycoflora of grain Maize (Zea mays L.) stored in traditional storage containers (Gombisa and Sacks) in selected woredas of Jimma zone, Ethiopia. African journal of food, agriculture, nutrition and development, 14 (2).

[17] Garcia-Diaz M, Gil-Serna J, Vazquez C, Botia MN and Patino B (2020). A Comprehensive Study on the Occurrence of Mycotoxins and Their Producing Fungi during the Maize Production Cycle in Spain. Micoorganisms, 8 (1), p. 141.

[18] Adetunji, M, Atanda O., Ezekiel CN, Sulyok M, Warth B, Beltrán E, Krska R, Obadina O, Bakare A. and Chilaka CA (2014). Fungal and bacterial metabolites of stored maize (Zea mays, L.) from five agro-ecological zones of Nigeria. Mycotoxin research, 30 (2), pp. 89-102.

[19] Negasa F, Solomon A and Girma D (2019). Effect of traditional and hermetic bag storage structures on fungus contamination of stored maize Grain (Zea mays L.) in Bako, Western Shoa, Ethiopia. African Journal of Food Science, 13 (3), pp. 57-64.

[20] Sharma A and Sharma K (2012). Protection of maize by storage fungi and aflatoxin production using botanicals.

[21] Aminu M and Keta JN (2021). Study of Fungi on Stored Maize (Zea mays L.) in Kebbi State, Nigeria. Journal of Current Opinion in Crop Science, 2 (1), pp. 55-59. 